hazards arising from the emission of aromatic and hydrocarbon amines. But legislators have indicated that they are more concerned about producing energy than meeting social and environmental costs - and are unlikely to produce much extra money for research into the latter.

Neither has much been done to calm the fears that a programme on the scale envisaged by the administration - initially aimed at producing 500,000 barrels a day by 1985 and 2 million by 1990 - is overambitious, and likely to encounter problems such as an inadequate technology base and a severe shortage of appropriately qualified scientists and engineers.

Typical reservations were expressed at a two-day meeting organised last October by the National Academy of Sciences, and attended by a cross-section of industrial and academic scientists and engineers. This reached the conclusion that the 1985 deadline could not be met, but would require six to eight years to achieve.

The meeting also pointed out that reaching the 1990 target would require second stage technologies to be selected before the results of the first stage had been properly analysed.

Following these and other similar criticisms, the administration's initial proposals have been tempered. Thus the President has agreed that the initial cost of $\$ 88$ billion be broken down into two stages, with Congress committing itself only to $\$ 20$ billion in the first four years.

Following widespread opposition from the oil industry over what it considered to be excessive federal involvement and unfair competition, the president has also agreed that the synthetic fuels corporation which will be responsible for the programme will not have the authority to construct and run its own plants, but merely assist the private sector to do so.

Furthermore members of the Senate and the House of Representatives, meeting last week to resolve differences in their respective versions of the synfuels legislation, agreed that the dealines for the 500,000 and 2 million barrels a day targets be set back to 1987 and 1992 respectively.

But the major thrust of the administration's strategy of pushing for ambitious production goals remains in place. These goals had been strongly supported by the Senate, but opposed by the House which had proposed a more modest package - costing only $\$ 3$ billion and with no new corporation - and suggested a greater emphasis on conservation measures to meet the same goals.

As far as manpower needs are concerned, Dr Alex K. Logwunik of Pullman Kellog, one of the largest engineering firms in the country, estimated last month that the proposed synfuels programme could absorb $20 \%$ to $60 \%$ of the capacity of the ten major engineering firms in the country. And he warned that the result could be a series of shortages of qualified personnel, already beginning to affect other areas of energy technology.

Supporters of the synfuels programme, however, argue that similar claims had been expressed before other large-scale national efforts, such as the Apollo moon landings. And that once the programme is under way, it will stimulate a flow of research workers and technical people from other areas.

Critics are unconvinced. But in an election year both Congress and the White House are keen to be seen to be doing something about the energy problem and responding to the frustration of constituents takes precedence over the finer logic of technological timeliness.

David Dickson

\title{
Split over nuclear export licensing
}

FACED with growing difficulties in implementing its non-proliferation policies, the Carter administration is seeking to simplify its task by removing an independent check on the adequacy of safeguards covering nuclear export currently provided by the Nuclear Regulatory Commission.

The NRC itself is split over whether such a move is desirable, but it is being strongly resisted in Congress, for in passing the Nuclear Non Proliferation Act of 1978, legislators specifically invoked the NRC to try to prevent the non-proliferation debate from becoming too politicised by remaining within the sphere of the State Department and the White House.

Under the terms of the Act, the NRC is required to evaluate whether facilities to which nuclear fuel or technology is being exported contain sufficient technical and institutional safeguards to ensure that neither could be diverted to military purposes. However its decision to reject a license application can be overturned by the President - whose decision can in turn be reversed by Congress.

In recent weeks, the White House has been faced with a number of sensitive decisions on nuclear exports. Some in particular have been the direct result of the two-year time limit imposed when the Nuclear Non-Proliferation Act was signed in 1978, requiring nuclear shipments to be cut off after 10 March 1980 to all countries which had not renegotiated nuclear agreements along the lines of the Act.

Attempts to enforce controls on the export of enriched uranium to Europe, however, were bitterly resisted by leaders of the European Economic Community in the summer of 1978 , particularly because of the restrictions placed on the transfer of fuel originating in the US.

With the US administration's failure to generate a consensus behind its general strategy at the International Nuclear Fuel Cycle Evaluation (INFCE) meeting in Vienna last month, it is reluctant to provide further embarrassment.

So, last week President Carter agreed that, rather than bring an embargo into effect, western nations would be given permission to continue buying American enriched uranium as reactor fuels, even though they have not complied with the terms of the 1978 Act. The dispensation is allowed for one year, under the President's power to allow exemptions while negotiations are taking place.

A more difficult case is raised by India, which has persistently refused to sign the Nuclear Non-Proliferation Treaty or to accept international inspection of its nuclear facilities - two requirements for being granted export licenses under the $1978 \mathrm{Act}$ - as being unwarranted interference in internal affairs.

The Administration is being pushed by Congress and environmental groups to maintain a firm line in refusing to grant export licenses covering a shipment of 21 tons of uranium for nuclear power plants at Tarapur in India. Under the terms of the Act, nuclear shipments are now banned unless the President determines otherwise. However, President Carter is thought to be actively seeking ways of not offending Mrs Ghandi, indicating last week that he is now merely seeking assurances that the fuel will not be used for explosives, rather than any broader commitment - a decision that would probably be accepted by Congress.

In a separate domain, the US is actively engaged in trying to persuade Switzerland not to export to Argentina a facility capable of producing heavy water, which the administration feels could, as in India several years ago, be used to help produce weapons grade plutonium.

Officials in Washington are said to be worried not only about the fact that this would make it easier for Argentina to construct its own nuclear weapons, but also about what they see as a lax attitude by the Swiss authorities in demanding looser safeguards on nuclear exports than had been agreed in 1978 among the main supplier countries - including Switzerland.

Finally the US has so far been unable to get very far in developing an aid package acceptable to the Pakistani government which would both guarantee Pakistan adequate protection against any Soviet threat but also persuade it to give up its attempts - still denied by Pakistani officials - to produce a nuclear bomb.

Faced with these interlocking problems, Mr Gerard Smith, Assistant Secretary of State for non-proliferation issues, has been actively lobbying Congress for a change in the legislation that would remove the NRC from, as one state department official puts it, "second guessing the President on foreign policy issues". 